\title{
和釘と洋釘を併用する建物
}

\section{STUDY ON THE BUILDINGS USED THE JAPANESE NAIL AND THE WESTERN NAIL TOGETHER}

$\begin{array}{ll}\text { 平山育男 }-* 1 & \text { 木村 勉—— } \\ \text { 御船達雄—— } & * \text { 梅嶋 修—— }\end{array}$

御船達雄—— $* 3$

西澤哉子——

キーワード :

和釘, 洋釘, 併用, 明治時代中期

Keywords:

Wakugi (Japanese nail), Youkugi (Western nail), Combination, The middle of Meiji era

\section{Ikuo HIRAYAMA $* 1$ \\ Tatsuo MIFUNE — $* 3$ \\ Kanako NISHIZAWA — $* 5$}

This article examined the building used the Japanese nail and the Western nail together, and following points became clear.

The combination of the Japanese nail and the Western nail began in the advanced area early in the Meiji era and concentrated on it generally in the latter half from the Meiji early 10s.

There was a dual circulation period for the switch of the Western nail from the Japanese nail, and every use point was gradually rearranged from the Japanese nail to the Western nail.
1.はじめに

和釘から洋釘への転換は従来、明治 $20(1887)$ 年〜明治 $30(1897)$ 年頃とされ注1)、和釷から洋釷への製法の変遷注2) や同時代における 洋釘使用についても報告がなされている注3)。

ところで筆者らは修理工事報告書の記載や建造物の調査により、 建築年代を特定できる部位において和釘と洋釘を併用する建物を複 数事例見出した。本稿ではそれらの事例を通し、和釷から洋釷への 転換時期を示寸とともに、この転換がどのようにしてなされたのか を示すことを目的とする。

\section{2. 建築年代の判明する和・洋釘を併用する建物の事例報告}

先ずは管見の限りで明治時代初期から中期頃までの建築に関わる 国指定重要文化財などの修理工事報告書に当たった。以下に和釷と 洋釘の併用を記す事例などを挙げる注4)。

\section{2-1 北海道 函館開拓使レンガ倉庫（増築・内部改造）}

明治 18 (1885) 年に増築・内部改造を受けたとされるこの建物では、 一般に丸釘、屋根野地がい好釷であったという注5)。

\section{2-2 群馬県 旧群馬県衛生所}

明治 11 (1878) 年 8 月竣功の旧群馬県衛生所では、天井廻縁、楣、 間柱止、建具栈に角釷が使われ、その他の壁内外、床板、天井板、 胴縁、野地板止には洋釷が用いられたとする注6)。

\section{2-3 新潟県 新潟県議会旧議事堂}

明治 16 (1883) 年 3 月竣功の新潟県議会旧議事堂では、角釘を議事 天井蛇腹下地止に用い、それ以外は丸釷の使用と寸る ${ }^{2}$ 注7。

\section{2-4 静岡県 旧岩科学校校舎}

明治 $13(1880)$ 年 9 月竣功の静岡県旧岩科学校校舎で角釷と丸釷の
使用が確認されている。併用の部位は長押、敷居などの造作や軒蛇 腹木摺などで、洋釗の利用が最も多いのは床板と報告される注8)。

なお、建物を観察すると長押は修理工事で解体を免れ、創建時の 状態で釘止がなされる。1 階の長押はすべて洋釘止で、2 階中央棟廊 下の部屋境の長押にのみ和洋釘の併用が確認される。但しここでも 多くは洋釷止で、和釷は 3 か所となり、いずれも廊下に並ぶ部屋境 筋の柱に用いられる。和釷の長さを知ることはできないが、巻頭上 面の大きさと形状から、他で使用される長 2.45 寸の洋釷よりは太く 長い寸法と推測できる。このことから和釷は、柱背後に延びる間仕 切りの差鴨居などを意識し深く打ち込まれていると考えられる。そ の効果や理由は判然としないが、洋釘と和釘の使い分けが意識的に 行われたことは明らかである。

\section{2-5 兵庫県 旧神戸居留地十五番館}

旧神戸居留地十五番館は明治 13(1880) 年末から 14(1881) 年前半 の建築とされ、角釷と洋釷の使用が報告されている。角釷は貝折釷 が主で、煖炉木枠の煉瓦躯体への止め、母屋転び止めの上辺（下辺 は洋釷）、柱形煉瓦積押に用いられており、5 寸以上の長さと寸る。 洋釷は 2 階床板、蛇腹肋栈、野垂木、踊場根太、野地板、木摺など と使用が多く、104mm (4 インチか)以下で、長さによる使い分けが指 摘される注9)。

\section{2-6 愛媛県 釣島灯台旧官舎}

旧官舎と倉庫はお雇い外国人ブラントンの設計で明治 6 (1873) 年 に䇋功した。ここでは船釷が楣、貝折れ釷が垂木、受け木などの小 屋組注 ${ }^{10)}$ に、洋式釷は頭が円形の角断面で、羽目板、巾木、額縁等 の化粧材、木摺に用いられる。洋式釷は板金を交互にバチ型に裁断 し、頭部を造り出し、イギリスからの輸入品であろうとする注11。

\footnotetext{
長岡造形大学 教授・博士 (工学), 博士 (造形)

( T 940-2088 長岡市千秋 4-197)

長岡造形大学 教授・博士 (工学)

和歌山県教育委員会 博士 (工学)

(森)グリーンシグマ 博士（造形）

長岡造形大学デザイン開発研究所 研究員・修士（造形）
}

\footnotetext{
Prof., Nagaoka Institute of Design, Dr. Eng., Dr. Design

Prof., Nagaoka Institute of Design, Dr. Eng.

Wakayama Prefecture Board of Education, Dr. Eng.

Member of Green-Sigma Co., Ltd., Dr. Eng.

Researcher of Design Development Lab., Nagaoka Institute of Design, M. Design
} 


\section{2-7 愛媛県 旧広瀬家住宅主屋}

旧広瀬家住宅主屋は明治 10 (1876) 年の建築後、明治 20 (1886) 年に なって現地一移築を受けた。主屋では野地板を打ち付けた釷の内 $1 / 10$ 程度が和釘で、残りが洋釷とする注 12 。

\section{2-8 長崎県 東山手十二番館附属屋}

東山手十二番館は明治元 (1868) 年頃の建築と推定される。この内、 主屋と附属屋で明らかに当初と判明した金物で角釗は附属屋の㹂胴 縁止、丸釷では旧壁木摺止と旧下見板上張り止とされる注13)。

\section{2-9 長崎県 旧出津救助院授産場}

明治 16 (1883) 年完成の旧出津救助院授産場では舟釘、巻頭、階折、 角、洋釷が確認される。使用数が多い箇所は舟釘が 1 階内部棹縁受 け、北面棚根太、南面棚、開口部方立、2 階内部の根太、無目敷居、 2 階外部の雨戸敷鴨居、吊柱とする。巻頭は 2 階内部の無目敷居、2 階外部の胴縁、階折は 1 階内部の天井板、棹縁、北面棚壁板、北面 開口部鴨居、1 階外部の雨戸鴨居、幕板（内部とも）、2 階内部の天 井板、棹縁、幕板 (外部とも) とする。角は 1 階内部の北面棚床板、 南面付鴨居、1 階外部垂木、2 階内部床板とする。洋釗は 1 階外部化 粧裏板、2 階外部の壁板、垂木、野地板、化粧裏板とされる注14)。

\section{3．建築年代の判明する和・洋釘を併用する建物の事例報告}

次いで著者らによる建築調查により、建築年代の判明した箇所で 和釘と洋釷の併用が判明した建物について報告を行う注15)。

\section{3-1 新潟県新潟市 旧小澤家住宅奧座敷（写真 1) 注16)}

概要：旧小澤家住宅は新潟市中央区上大川前通に位置する。建物は 店、主屋、奥座敷、新座敷、離孔座敷、道具蔵、家財蔵などから構 成され、新潟市指定文化財とされる。

建物は上大川前通りに東面し、奥座敷は敷地中央奧に位置し、主 屋の北西に接続する。木造 2 階建寄棟造栈瓦葺で、1 階の上屋規模 は梁行 2 間半、桁行 5 間で、北面に半間巾の下屋が付く。踊場及び 2 階は梁行 3 間、桁行 4 間で、東側半間は出桁による迫出し、南側 半間は先行する主屋上に乗り、1 階の西側 1 間半は平屋建とする。

平面：1 階は西側より 8 帖、6 帖の続き座敷で、8帖側に床飾り、東 側に階段を設ける。階段をのぼると踊場があり 2 階へ至る。また、 階段東側に後補の蝶の間が接続する。2 階は 10 帖 1 室で西側に床飾 りを設け、残る三方に廊下を迴し周囲を眺望することができる。

建築年代：この建物からは明治 19 (1886) 年 10 月、12月の墨書と同 年 9 月の年紀を持つ新聞紙が見出されたことから、明治 $19(1886)$ 年 の建築と判断できる。墨書は 2 階床梁、踊場敷居に記され、新聞紙 は 1 階の柱養生に用いられ、直接土壁の施工がなされたことから、1 階・踊場・2 階は一連の建築と考えることができる。
和釘と洋釘：原則的に洋釷の使用であるが、構造材の接合には和釘 も用いられる。使用される和釷の長さは 3.5 寸、 4 寸と比較的大型 であった。また、壁下地となる竹小舞の貫への固定にも部分的に和 釘の使用が認められた。なお、当住宅は明治 $13(1880)$ 年の大火で道 具蔵本体を残し前身建物が焼失し、奥座敷に先行し建築された店、 主屋、道具蔵(覆屋) は和釷の夕の使用、奥座敷以後に建築された建 物は洋釘のみによる建築となる。

\section{3-2 長岡市東竹沢 旧星野家住宅主屋（写真 2) 注17)}

概要：旧星野家住宅主屋は長岡市東竹沢に位置した住宅である。建 物は平成 16 (2004) 年の中越地震により被災し、主屋を長岡市が譲り 受け平成 18(2006) 年に部材の解体保存を行い、平成 26(2014) 年に一 部の部材を用い、越後丘陵公園に移築がなされた。

解体前の主屋は東面し、木造 2 階建で一部に中 2 階を設け、入母 屋造金属板莫平入、規模は桁行 11 間半、梁行 7 間半であった。

平面：主屋には正面中央に配されるゲンカンから入る。下手は 3 間 四方の板敷となるニワで、下手がサギョウシツとなる。裏側がやは り 3 間四方の板敷のダイドコロで、この部屋の上手隅部に大黒柱が 立つ。一方、ゲンカンからカミゲンカンを進むと廊下がコの字に配 され、この内側に 8 帖、6 帖の居室 2 室が置かれる。そしてこの上 手に 10 帖のマエザシキ、裏側には下手に 4 帖の仏間、上手に 8 帖で トコ、タナ、平書院を持つオザシキを構えた。

建築年代 : 主屋は明治 17 (1884) 年の登記で、聞き取りによれば完成 まで 3 年の歳月をかけての建築と伝承される。

和釘と洋釘：長押の取り付けで 8 帖、6 帖の居室に分割された旧チ ヤノマは和釷によるものであったが、ブツマ南面の内法長押は 1 材 で西側が和釷、東側が洋釘による取付であった。また、屋根では当 初材である木端板の据付は和釘、外周の壁も下地はほとんど洋釷止 であったが、その表側となる下見板の柱への据付は和釷であった。

\section{3-3 三島郡出雲崎町尼瀬 旧津山家住宅店舗兼主屋}

概要 : 旧津山家住宅主屋は出雲崎町尼瀬に位置し、出雲崎町に寄贈 されている。店舗兼主屋は旧北陸街道に南面し間口 3 間半、奥行は 12 間半となる木造 2 階建で、切妻造妻入セメント瓦莫とする。

平面：建物は東側に通り土間が背面まで配され、1 階ではこれに面 して 1 列で、正面側から店、茶の間、中の間、寝間の 4 室を置き、 廊下を介して中庭となる。2 階は店の上が表二階、茶の間は吹き抜 けとなり、背面は裏の小間、裏二階となる。

建築年代: 建物では裏の小間の襖下地に明治 16(1883) 年 3 月の新聞 が確認され、これを上限とする建築と考えることができる。

和釘と洋釘：和釷の使用が垂木と正面下屋垂木掛の取り付けで確認 され、洋釷は 2 階際根太などで見ることができた。

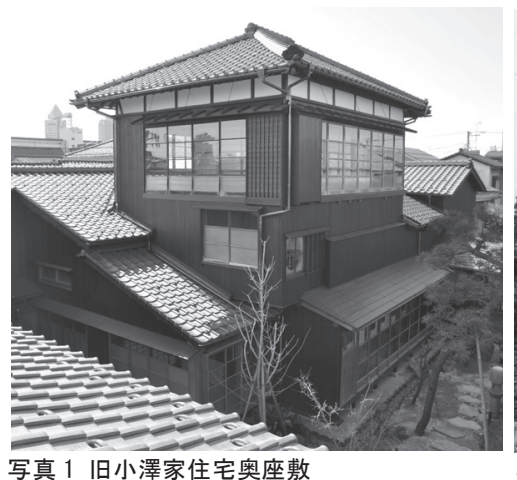

写真 1 旧小澤家住宅奥座敷

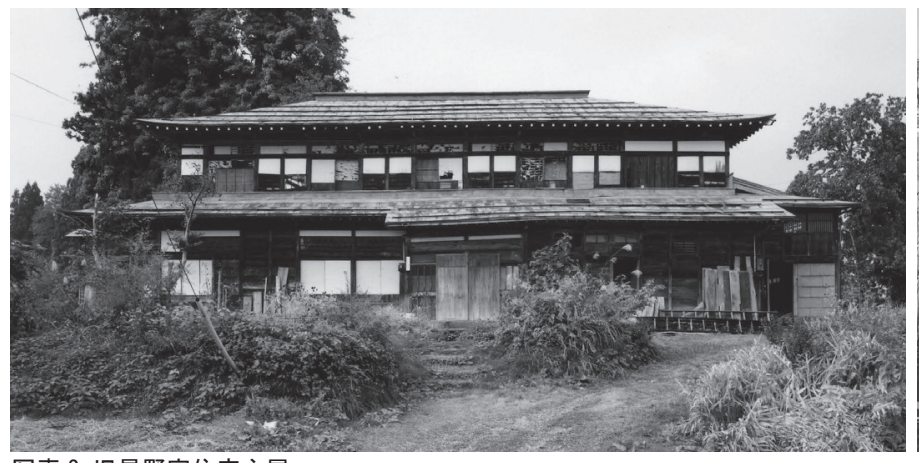

写真 2 旧星野家住宅主屋

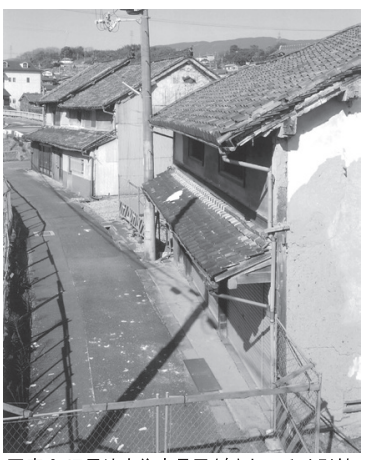

写真 3 旧恩地家住宅長屋(奥)とみそや別館 


\section{3-4 橋本市橋本 みそや呉服店別館店舗兼主屋 (写真 3) 注 18)}

概要：みそや呉服店別館は橋本市橋本に位置し、旧大和街道に南面 した敷地を構える。この建物は桁行 5 間、梁行 5 間、切妻造栈瓦莫 2 階建で国の登録有形文化財とされる。屋根はむくりで、全体に数 寄屋の趣向が凝らされ、下手となる土間廻りはいわゆる京風の「表 屋造り」を変形したもので、正面側ミセから一度吹き抜けの外部空 間に出てからゲンカンに客人を迎え入れる構成となる。

平面：街道に面した建物正面側は揚戸、大戸を構えミセとなる。下 手が通り土間で奥が台所となるが、その途中が一度外部となり、こ の上手がゲンカンとなる。ミセ裏側は現状では 3 室の構成で、上手 が 6 帖 2 室の続き座敷となる。2 階はミセから上がり、正面側はツ シ二階、背面は続き間の書院座敷となるが長押は打たない。

建築年代 : 2 階天井裏に棟札が残され、明治 17 (1884) 年の建築が明 らかとなる。なお、大工は京都の政田佐平衛、政田浅次郎の 2 人と、 橋本の木澤新兵衛の名が記され、京都から技術者を招聘して、京風 の町家が建設された稀有な事例とされる注19)。

和釘と洋釘：棟札は長さ $45 \mathrm{~mm}$ となる 2 本の洋釘で大黒柱に打たれ、 2 階座敷の天井釣木も洋釷であった。一方、一階物入れの床板、階 段裏板の目板に和釘を確認した。

\section{3-5 橋本市橋本 旧恩地家住宅長屋 (写真 3$)^{\text {注20) }}$}

概要：旧恩地家住宅は橋本市橋本に位置し、橋本市の中心市街地再 開発事業により平成 27 (2015) 年に除去された。なお、この建物は前 述したみそや呉服店別館店舗兼主屋の 2 軒隣の敷地であった。

長屋は 2 階建の切妻造平入栈瓦莫で、規模は桁行 7 間半、梁行 4 間で、正面の南側と背面北側に半間の下屋が取り付き、正面の 2 階 壁面を塗り込め虫籠空を設ける。東側の間口 4 間が恩地家、西側の 間口 3 間程が辻家で、後者の棟高さが $30 \mathrm{~cm}$ 程高い。

平面：恩地家側の 1 階床上は田の字形の 4 室で表の東側は 2 間半四 方でこの表側は一部を土間とする板敷とする。奥の座敷は床の間付 きの 8 帖でとする。下手西側表側は奥行 2 間半の土間で、傍らに暗 室を設け、かつて読売新聞橋本支局とされた。裏側へ半間巾の通り 土間が続き、 8 帖座敷前室の 4 帖が取り付き、背面を台所とする。 2 階は 4 帖から登る。表側が上手 8 帖、下手を 6 帖とする続き座敷で、 北東部は一段上がり物置とする。
辻家の 1 階は表側が土間と変形の 6 帖、裏側は板の間 2 室で土間 の台所、背面に便所を設ける。2 階は背面東側の板の間から上がり 表側が 8 帖、裏側が 6 帖と 4 帖の続き座敷とする。

建築年代：恩地家側の棟木に無記銘の幣串が洋釗止され、別置の資 料として明治 18 (1884) 年の “ふしん入用ヒカア帳” が確認されたこ とから、建物は明治 18 (1884) 年と判断できた。旧辻家の側はほぼ洋 釘の仕事で、少し下った時代に分割を行って棟を上げ、2 階の座敷 を整備する仕事が確認された。旧辻家側には無記名で 2 本の幣串が 洋釘止されていた。この工事は明治 26 (1893) 年の年紀を持ち、大工、 左官などの記載がある “手伝祝儀帳”が見い出され、これが旧辻家 側を分割した工事記録と判断した。

和釘と洋釘：恩地家側の幣串や、床の間の壁下地は洋釘止であった が、1階 8 帖の廻縁が和釘止であった。

\section{4. 和・洋釘を併用する建物の建築時期}

各事例を表 1 にまとめた。これによると和洋釘を併用する建物の 建築年代は、東山手十二番館附属屋が明治元 (1868) 年とやや古く、 長崎における先進事例と見なすことができる。また、明治 6 (1873) 年の釣島灯台は、本格的な洋式建築において日本的な要素を中心に 用いられた事例と見ることができる。但し、過半は明治 11(1878)年 の旧群馬県衛生所、明治 13 (1880) 年の旧岩科学校校舎、旧神戸居留 地十五番館など明治 10 (1877) 年代前半に始まり、明治 16(1886) 年の 新潟県議会旧議事堂、旧出津救助院授産場、旧津山家住宅主屋、明 治 17 (1884) 年のみそや呉服店別館店舗兼主屋、同年の旧星野家住宅 主屋、明治 18 (1884) 年の旧恩地家住宅長屋、函館開拓使レンガ倉庫、 明治 19 (1885) 年の旧小澤家住宅奧座敷、明治 20 (1887) 年移築の旧広 瀬家住宅主屋など、明治 10 (1877) 年代後半にかけ多くが集中する。

\section{5. 和・洋釘の使用個所}

表 1 によると、和釷の使用が目立つのは、構造材（旧小澤家）や 天井廻縁（旧群馬県衛生所、旧恩地家住宅）、階段目板目（みそや別 館)、長押（旧岩科学校、旧星野家住宅）など目につきやすい部分と なる。一方、洋釘の使用箇所は、棟札（みそや別館）、幣串（旧恩地 家住宅）の打ち付け、天井釣木（みそや別館）、壁下地（旧群馬県衛

表 1 和釘と洋釘を併用する建物と和洋釘の使用個所

\begin{tabular}{|c|c|c|c|c|c|}
\hline 建物名 & 所在地 & 建築年代 & 根拠 & 和釘の使用個所 & 洋釗の使用個所 \\
\hline 東山手十二番館附属屋 & 長崎市 & 明治元 (1868)年頃 & 報告書 & 㹂胴縁 & 旧壁木摺止と旧下見板上張 \\
\hline 釣島灯台旧官舎 & 松山市 & 明治6(1873)年 & 報告書 & 船釘が楣、貝折れ釘が垂木、受け木などの小屋組 & $\begin{array}{l}\text { 頭が円形の角断面の洋式釘: 羽目板、巾木、額縁 } \\
\text { 等の化粧材、木摺 }\end{array}$ \\
\hline 旧群馬県衛生所 & 前橋市 $※ 1$ & 明治11(1878)年8月竣功 & 報告書 & 天井廻縁、相、間柱止、建具栈 & 壁内外、床板、天井板、胴緑、野地板止め \\
\hline 旧岩科学校校舎 & 賀茂郡松崎町 & 明治13(1880)年9月 & 報告書 & 長押、敷居などの造作や軒蛇腹木摺 & 長押、敷居などの造作や軒蛇腹木摺、床板 \\
\hline 旧神戸居留地十五番館 & 神戸市 & \begin{tabular}{|l|} 
明治13(1880)年末～14(1881)年 \\
前半
\end{tabular} & 報告書 & $\begin{array}{l}\text { 煖炉木枠の煉瓦躯体への止め、母屋転び止め上 } \\
\text { 辺、柱形煉瓦積押え(長さ5、以上) }\end{array}$ & $\begin{array}{l}\text { 2階床板、蛇腹肋栈、野垂木、踊場根太、野地板、 } \\
\text { 木摺 }\end{array}$ \\
\hline 新潟県議会旧議事堂 & 新潟市 & 明治16(1883)年3月 & 報告書 & 議事天井蛇腹下地止 & 一般 \\
\hline 旧津山家住宅 & 三島郡出雲崎町 & 明治16(1883)年頃 & 新聞紙 & 垂木 & 2階際根太 \\
\hline $\begin{array}{l}\text { みそや长服店別館店舗 } \\
\text { 兼主屋 }\end{array}$ & 橋本市橋本 & 明治17(1884)年上棟 & 棟札 & \begin{tabular}{|l|} 
一階物入れ床板 \\
階裹目板
\end{tabular} & $\begin{array}{l}\text { 棟札打ち付け } \\
\text { 二階天井釣木 }\end{array}$ \\
\hline 旧星野家住宅主屋 & 屒岡市東竹沢 & 明治17(1884)年竣功 & 登記 & $\begin{array}{l}\text { 長押 } \\
\text { 垂木、木端板、外周下見板 }\end{array}$ & $\begin{array}{l}\text { 長押 } \\
\text { 壁下地 }\end{array}$ \\
\hline 旧恩地家住宅長屋 & 橋本市橋本 & 明治18(1884)年普請 & 文書 & 一階座敷廻縁 & $\begin{array}{l}\text { 幣串打ち付け } \\
\text { 床の間壁下地 }\end{array}$ \\
\hline 函館開拓使レンガ倉庫 & 函館市 & 明治18(1885)年増築・内部改造 & 報告書 & 屋根野地 (いぬ釘) & 一般 \\
\hline 旧広瀬家住宅主屋 & 新居浜市 & \begin{tabular}{|l} 
明治10(1877)年建築 \\
明治20(1887)年移築
\end{tabular} & 報告書 & 野地板 & 野地板 \\
\hline
\end{tabular}

凡例: 網掛けは修理工事報告書の記載による $※ 1:$ 当初の建築場所 $※ 2:$ 角(釘)の使用個所 
生所、旧星野家住宅）などで、敢えて言えば目につきづらく、数量 の多い部分での使用が目立つと言える。また、長大材を和釷とした 事例（旧神戸十居留地五番館、旧小澤家住宅奥座敷）も報告される。

\section{6. 和釘から洋釘への転換期における和釘と洋釘利用のあり方}

日本で初めて洋釷の国産化に取り組んだとされる安田善次郎は、 著書である『釘』の中で “交代期に於ける和洋釘優劣の批評”とし て、洋釷が出回った明治時代における状況を

洋釷の渡り始めなども《中略》種々の避難を免れませんでした。 と語り、非難の内容として次の“い”から“に”の４項目をあげる。

い、釘は其徸四角なればこそ、利きが好きなれ、然るを、洋釗 のやうに、茎が靓くては、十分に利く筈無く、日ならずして抜 け出す恐れ有らう。

ろ、釷の茎は、其尜より頭まて、錐体になつて居ればこそ、楔 の理に督て肯く物体に刺さる〉なれ、然るを、洋釘の茎のや うに、端が劣るだけで其の他が同じ太さでは、其の長さの割に は、効力が有るまい。

は、洋釘の茎は、錐体を成して居ない為めに、之を打ち込む時 に、無理を生じ、従つて曲り易い

に、洋釷は、和釷に比すれば錆易く、黒いしみを生じて、体裁 上見にくい、などの避難がありました、大工中には、之を用ひ るのを罪悪のやうに思ふ者もあり、殊に建築主は、不安心なこ の釷を用ひるのを䈌く好まず、洋釷を用ひざるを、請負契約書 中の一条件とする人さへ有りました、が、洋釷は、第一其俉が 甚だしく安く其形体上から言えば、蓋に鉄棺の滑り止めが有る 為めに、打ち込む時に曲るといふ杞憂も無く、頭にぎざこの刻 みが有る為めに、脱け出でもせず、和釘に比して稍長みのもの を使へば、さしたる劣点の無いことが、追々知れて来まして、終 に、全く和釷に代り、和釘の株を奪ふやうになりました售21)。

以上、本稿で見てきたように和釷から洋釷の転換へは一定の期間 があったと見ることができる。特に旧恩地家住宅長屋とみそや呉服 店別館店舗兼主屋は 1 軒を挟んだ至近距離に位置し、橋本の地では 少なくとも数年の移行期間を想定できる。また、新潟においても旧 小澤家住宅奧座敷と新潟県議会旧議事堂は直線距離で $1.6 \mathrm{~km}$ 離れて いるに過ぎず、建築年代には 3 年余りの開きがある。

そして移行期間に施主と大工の間では、この新しい材料に対する 様々な葛藤のあったことが安田の記録からも伝わる。引用中 “い” “ろ”の問題点は、洋釘が抜けやすい、“は” は折れやすい、“に” は錆やすい、ということに対しての疑念で、施工後の見栄えを意識 したと言える。これらの危惧を上述の建物における和釷の使用個所 で見ると、和釷が長押、廻縁、外部の下見板などで遅くまで用いら れた点は、“に”の危惧を反映したと言える。また、引き抜きの恐れ がある垂木などで和釘を用いる点は “い” “ろ”に対する危惧と言え る。他方、壁中で洋釷の使用が早くから見られる点は、これが材料 を大量に用いるが目立たず、引き抜きも起こりづらいためであろう。

\section{7. まとめ}

和釘と洋釘を併用する建造物について修理工事報告書、調查事例 の紹介を通して、建築時期、和洋釷使用個所の相違などを検討した が、明らかとなるのは以下の諸点である。
1) 和釘、洋釘の併用は明治時代初期に先進的な地域で始まり、一 般には明治10 (1877) 年代前半から見られ、後半期までに集中する。 2 ) 和釷から洋釷の転換には移行期間があり、釷の使用箇所ごと、 徐々に和釘から洋釘へ置き換えられた。

3 ) 和釘と洋釘を併用する建築で、和釘は通常望見がかなう箇所や、 力の掛かりや寸い箇所、長大材が遅くまで残った。一方、大量に 釘を用い目立た壁中などは早い段階から洋釷への転換があった。

\section{参考文献}

1) 安田善三郎: 釘、1916. 12

2) 福本都治: 和釷から洋釷へ一製釘技術の転換一、住まいと建築 $497 、 4 ２ 2$ 頁、 2002.2

3)御船、平山：橋本における明治中期の京風町家について、民俗建築 118、 pp. 56 62、2000. 11

4)平山ほか : 恩地家住宅長屋について 橋本の長屋建築その 20 和歌山県橋本 市中心市街地の町之町家の調査研究 その $140 、 2015$ 年度日本建築学会大会 学術講演梗概集 F-2、pp. 277〜278、2015.9

5) 新潟市：新潟市文化財旧小澤家住宅整備工事報告書、2011.3

6) 平山 : 長岡市 (旧山古志村) 星野家住宅の建築年代と使用された釘について、 2007 年度日本建築学会大会学術講演梗概集 F-2、pp. 87 88、2007. 8

注

注1）参考文献 1) 121 頁。“和釘と洋釘との交代は無論都鄙に依りて遅速有り ま寸が、概して、明治二十年ころから、三十年ころの間にあつたやうに思 われます。東京市内などは、明治二十年ころまでに、悉皆洋釗の勢力に征 服されて仕舞ひましたが稍離れた地方では、明治二十七八年ころまで、尚 角釘を打ち出して居り”とする。

注2）参考文献 2)

注3）青梅市郷土博物館：『青梅市の社寺建築』付録 造営資料、68 頁、昭和 $63(1988)$. 3。青梅市の下山八幡神社では明治 25 (1892) 年 9 月の日付を持つ 領収書に“丸釷壱貫三百多”に“五十八銭五厘” の支払が記録される。

注4）以下の修理工事報告書からの事例報告では、当該の報告書において用い られている釷の呼び名や記載を用いた。

注5）財）文化財建造物保存技術協会: 重要文化財豊平館保存修理工事報告書、 196～197 頁、昭和 61 (1986).7。ここで云う“いぬ釗”とは舟釷であろう。

注6）財）文化財建造物保存技術協会、桐生市教育委員会 : 重要文化財 旧群 馬県衛生所修理工事報告書、38 頁、昭和 61 (1986). 3

注7）財）文化財建造物保存技術協会：重要文化財 新潟県議会旧議事堂修理 工事報告書、53 頁、昭和 49 (1974). 3

注8) 松崎町：重要文化財旧岩科学校校舎修理工事報告書、57 頁、平成 5(1993). 3

注9）財) 文化財建造物保存技術協会: 重要文化財 旧神戸居留十五番館保存修 理工事報告書、39 頁、平成 5(1993). 3

注10）阿瀬真由香、藤岡洋保：D.\&T. スティブンソンの仕様書と R. H. ブラ ントンが建築した灯台、2003 年度日本建築学会大会学術講演梗概集 F-2、 618 頁、平成 15 (2003). 10、によれば、ブラントンによる仕様書では吏員退 息所における屋根回りがスコットランドにおいて教育を受けた陸屋根の形 式とは異なり、勾配を伴うものとなっているとの指摘がある。

注11）松山市：松山市指定文化財 釣島灯台旧官舎修理工事報告書、58 頁、 平成 10 (1998). 3

注12）旧広瀬邸文化財調查委員会：別子銅山の近代化を見守った広瀬邸一旧 広瀬邸建造物調査報告書-、61 頁、平成 $14(20029.3$

注13）財) 文化財建造物保存技術協会: 重要文化財 東山手十二番館 主屋 - 附 属屋保存修理工事報告書、61 頁、平成 $17(2005)$. 3

注14）公益財団法人文化財建造物保存技術協会: 重要文化財旧出津救助院授 産場ほか 1 棟建造物保存修理工事報告書、165 頁、平成 24 (2012). 8

注15）以下、本文に挙げる 5 事例の他、和釘と洋釷を併用する住宅としては 平山、御船らが調査を実施した稲城市の篠崎益朗家住宅主屋がある。稲城 市教育委員会生涯学習部社会教育課: 稲城市の民家建築、128 頁、平成 11(1999). 3。この建物では土壁中の貫に間渡し止める釘に和釘と洋釷を併 用するが、建築年代を示す 1 次資料が見出せず、建物調査の結果、主屋は 明治時代中期の建築と判断した。

注16）参考文献 3） 72～75、228～232 頁参照

注17）参考文献 4) 参照

注18）参考文献 5) 参照

注19）大場修: 近世近代町家建築史論、481 頁、中央公論美術出版、平成 16 (2004). 12

注20）参考文献 6) 参照

注21）参考文献 1)、122１24 頁。なお、原文にある読み仮名を一部の漢字に 付した。

[2015 年 10 月 6 日原稿受理 2015 年 12 月 9 日採用決定］ 